\title{
Estimation of Growth Curves of Awassi Sheep by Isotonic Regression Analysis
}

\author{
İvesi Koyunlarının Büyüme Eğrilerinin İzotonik \\ Regresyon Analizi ile Tahmin Edilmesi
}

\section{Aycan Mutlu YAĞANOĞLU(D)}

Atatürk University, Faculty of Agriculture, Department of Animal Science, Erzurum, Turkey

\begin{abstract}
This study used isotonic regression analysis to classify non-linear regression models that were used to describe the growth curve in relation to different quality fit criteria. The best model selection was made by using the weight-age data obtained from Awassi sheep. Ten non-linear models measured by the fit quality determination coefficient, Akaike information criterion, Bayesian information criterion, mean quadratic estimation error, and estimated coefficient of determination were used. As a result of different non-linear models that were used to predict the growth curves of Awassi sheep and the isotonic regression analysis applied to these models, considering the Mean Square Error and $\mathrm{R}^{2}$ values, the Von Bertalanffy model turned out to be the most appropriate model. As a result, it was revealed that the percentage of predictability and goodness of fit of the models increased significantly with isotonic regression analysis, and as a result, more consistent adult weight estimations could be made.
\end{abstract}

Keywords: Awassi, growth curves, non-linear models, isotonic regression

\section{öz}

Bu çalışmada farklı kalite uyum değerlendiricileri ile ilişkili olarak büyüme eğrisini tanımlamak için kullanılan doğrusal olmayan regresyon modellerini sınıflandırmak için izotonik regresyon analiz yöntemi kullanmıştır. İvesi ırkı koyunlarından elde edilen ağılık-yaş verileri kullanılarak, en iyi model seçimi yapılmıştır. Uyum kalitesi belirleme katsayısı, Akaike bilgi kriteri, Bayes bilgi kriteri, ortalama ikinci dereceden tahmin hatası ve tahmin edilen belirleme katsayısı ile ölçülen on adet doğrusal olmayan model kullanıımıştır. İvesi koyunlarının büyüme eğrilerini tahmin etmek için kullanılan farklı lineer olmayan modeller ve bu modellere uygulanan izotonik regresyon analizi sonucunda MSE ve $\mathrm{R}^{2}$ değerleri dikkate alındığında Von Bertalanffy modelin en uygun model olduğu ortaya çıkmıştır. Sonuç olarak, izotonik regresyon analizi ile modellerin tahmin edilebilirlik yüzdesinin ve uyum iyiliğinin önemli ölçüde arttığı ve bunun sonucunda daha tutarlı ergin canlı ağırlık tahminlerinin yapılabileceği ortaya çıkmıştır

Anahtar Kelimeler: İvesi, büyüme eğrileri, lineer olmayan modeller, izotonik regresyon

\section{Introduction}

Kabul Tarihi/Accepted: 25.11 .2021

Sorumlu Yazar/Corresponding Author: Aycan Mutlu YAĞANOĞLU

E-mail:myagan@atauni.edu.tr

Cite this article as: Yağanoğlu, A. M. (2022). Estimation of Growth Curves of Awassi Sheep by Isotonic Regression Analysis. Atatürk University Journal of Agricultural Faculty, 53(1):67-70.

\section{(c) (i) (5)}

Content of this journal is licensed under a Creative Commons Attribution-NonCommercial 4.0 International License.
The emergence of inconsistency in weight-age data leads to the inability to use algorithms that were used to estimate the parameters of growth models, resulting in low goodness of fit of these models (Silveira et al., 2011). These adverse events are caused by reductions in weight over time due to environmental factors, including nutrient deficiencies, diseases, and general mismanagement. Mendes et al. (2009) studies Hereford cattle reared in the south of the country and Silveira et al. (2011) studies from crossbred lambs (Dorper $\times$ Rabo Largo) mentioned these decreases in growth curves.

These negative features can be eliminated by using a data transformation method that takes into account the expected values of the growth curve. Ramsay (1998) and Hussian et al. (2004) proposed a data transformation based on isotonic regression as a suitable technique to pre-correct longitudinal observations with such drawbacks. Gunn and Dunson (2005) applied this conversion to progesterone concentration data and were able to eliminate oscillations that prevented the fit of normal regression models. 
Kesbi and Notter (2016) stated that male lambs are heavier at birth, they grow faster until weaning, and therefore, they have higher body weight than female lambs at weaning. However, additive genetic correlations for body weight traits between male and female lambs were high, and these traits were thought to be controlled by similar genes.

Aytekin et al. (2009) mentioned that linear, cubic, and quadratic models can be used to identify the growth of the 2 month fattening period in Akkaraman and Anatolian merino lambs.

Native cattle breeds in the Northeast of Brazil have been adapted to the soil and climatic conditions of this region, thus achieving good growth performance in conditions almost always restricted to breeding other breeds. Malhado et al. (2009) stated that one of the ways to increase meat production in this region is by crossing local breeds with specific exotic breeds for meat production, such as the Dorper breed. Carneiro et al. (2007) noted that the success of such crosses can be effectively evaluated through the analysis of the growth curves of animals that relate weight to predefined time intervals.

The aim of this study is to estimate the growth curves of Awassi sheep, whose body weight decreases in certain age groups, using isotonic regression analysis and non-linear models.

\section{Material and Methods}

The animal material of the study consisted of 2-5 years old 22 Awassi sheeps. Data from sheeps were taken from Atatürk University application and research farm in Erzurum.

\section{Isotonic Regression}

Let $X=\left\{X_{1}, X_{2}, \ldots, X_{k}\right\}$ be a finite set provided by a binary relation $(\varepsilon)$ between the elements of $X$. This type of binary relationship is a simple order when the properties are provided:

(1) reflective: $x \prec x$ for all $x € x$;

(2) transitive: $x, y, z € X, x<y$ and $y<z$ then $x<z$;

(3) anti-symmetric: $x, y € X, x<y$ and $y \prec x$ then $x=y$; $e$;

(4) every element of $X$ is comparable: $x, y, z € X$, implies that, $x \prec$ $y$ where $y<x$.

Definition 1. A function $f:(X, X) \rightarrow R$ is said to be isotonic if

$x 1<x 2 \rightarrow \mathrm{f}(x 1) \leq \mathrm{f}\left(x_{2}\right)$

Definition 2. A positive $\omega: X \rightarrow R$ function is called a weight function.

Definition 3. Let $\mathrm{g}$ be a function on $\mathrm{X}$. a function $\mathrm{g}$ is an isotonic regression of $\mathrm{g}$ with weight $\omega$ if and only if $\mathrm{g}$ is an isotonic function and minimizes.

$$
\sum_{x \in X}[g(x)-(f(x))]^{2} \omega(x)
$$

where $\mathrm{f}$ varies among all isotonic functions in $\mathrm{X}$. Therefore, $\mathrm{g}^{*}$ is a restricted least-squares solution for expression.

Isotonic regression is generally done on two types of data sets; sets with a simple ordering of observations and sets with a quasi ordering of observations. In the current study, only isotonic regression theories based on simple order have been considered, following the notation by Barlow et al. (1972).

The non-linear regression models presented in Table 1 were adapted to the mean weight-age data of sheep using the Gauss-Newton algorithm, the ordinary least squares method, to compute goodness-of-fit criteria mentioned above, the codes in the R software were written (R Core Team, 2014). For all models shown in Table 1 (Silveira, 2010), parameter 1 represents the adult weight of the animal, 2 has no practical interpretation, and parameter 3 maturity rate. Models presenting parameter 4 have a variable inflection point, and other models have a fixed inflection point that was assumed for all models.

Five goodness-of-fit criteria are given as follows: adjusted coefficient of determination ( $\mathrm{R}^{2} \mathrm{adj}$ ), Akaike information criterion (AIC), Bayes information criterion (BIC), mean squared prediction error (MEP), and prediction determination coefficient $\left(\mathrm{R}_{\mathrm{p}}^{2}\right)$. The statements of these criterias are also presented in detail in Silveira (2010).

\section{Results and Discussion}

Table 2 shows the results of criterias of the goodness of fit for each model.

Considering the $\mathrm{R}^{2}$ aj value, the highest value was obtained as Richards and Gompertz (0.9966), Brody (0.9963), and Von Bertalanffy (0.9961). In line with the low MEP values, the lowest values were detected as Von Bertalanffy (0.4036), Brody (0.4841) and Richards, and Gompertz (0.4884), respectively. Considering the coefficient of determination values, the models with the highest values were determined as Richards and Gompertz (0.9996) and Brody and Von Bertalanffy (0.9991), respectively. Also, the AIC and BIC values, which we expect to be low, are Richards, Gompertz, Brody, Meloun II, and Mitscherlich, respectively, considering the models. The mean $\mathrm{R}^{2}$ aj value of 10 different models discussed in the study was obtained as 0.9891, and the values of all nonlinear models except the Schnute model are above this mean. According to the standard deviation values, the lowest value was obtained in $\mathrm{R}_{\mathrm{P}}^{2}(0.0031)$, and the highest standard deviation occurred in AIC (6.0329). According to the coefficient of variation values, the lowest coefficient of variation was $\mathrm{R}_{\mathrm{p}}{ }_{\mathrm{P}}(0.3122)$ and the highest coefficient of variation was found in MEP (124.3532).

Table 3 shows the best goodness of fit in the elderly compared to the four models available.

$100 \%$ unpredictable from the facility were used for the two models. Isotonic regression reconstruction at different weights (88\%) by realization ( $84 \%$ ) makes a small adjustment in the percentage of prediction for the Brody model.

Von Bertalanffy model showed the lowest value (11.7538) in terms of MSE. Lewis et al. (2002) obtained that in Suffolk sheeps, the Gompertz model is more suitable for estimating growth. Aytekin et al. (2010) mentioned that the highest $\mathrm{R}^{2}$ values were determined from Cubic, Quadratic, and Gompertz models. In addition, the isotonic transformations obtained according to the applied models have the expected effect on the fit of the Von Bertalanffy model. Therefore, considering the original data, isotonic regression transformed data with equal weights, and MSE values of isotonic regression transformed data, they were determined as $12.1208,13.4178$, and 11.7538, respectively. Although it was stated that the differences between the models did not have a very high effect, it was determined that the Von Bertalanffy model represented the best $R^{2}$ value (0.9954), especially as a result of the isotonic transformation with different weights. In Dağlıç and Kıvircik male lambs, Akbaş et al. (1999) and in Morkaraman and Awassi, Bilgin et al. (2004) reported that the Brody model is the best model for describing as unfit between body weight and age in 
Table 1.

Non-linear Regression Models to Describe Growth Curves

\begin{tabular}{|l|c|c|c|}
\hline Schnute & $y_{i}=\frac{\beta_{1}}{\left(1+\beta_{4} e^{\left(\beta_{3} \beta_{2}-x_{i}\right)}\right) \frac{1}{\beta 4}}+e_{1}$ & Meloun I & $y_{i}=\beta_{1}-\beta_{2} e^{\left(-\beta_{3} x_{i}\right)}+e_{1}$ \\
\hline Mitscherlich & $y_{i}=\beta_{1}\left(1-e^{\left(\beta_{3} \beta_{2}-\beta_{3} x_{i}\right)}\right)+e_{1}$ & Brody & $y_{i}=\beta_{1}\left(1-\beta_{2} e^{-\beta_{3} x_{i}}\right)+e_{1}$ \\
\hline Richards & $y_{i}=\frac{\beta_{1}}{\left(1+e^{\left(\beta_{2}-\beta_{3} x_{i}\right)} \frac{1}{\beta 4}\right.}+e_{1}$ & Von Bertalanffy & $y_{i}=\beta_{1}\left(1-\beta_{2} e^{\left.-\beta_{3} x_{i}\right)^{3}+e_{1}}\right.$ \\
\hline Gompertz & $y_{i}=\beta_{1} e^{\left(-e^{\left(\beta_{2}-\beta_{3} x_{i}\right)}\right)}+e_{1}$ & Michaelis-Menten & $y_{i}=\frac{\beta_{1} x_{1}}{x_{i}+\beta_{2}}+e_{1}$ \\
\hline Logistic & $y_{i}=\frac{\beta_{1}}{\left(1+e^{\left(\beta_{2}-\beta_{3} x_{i}\right)}\right)}+e_{1}$ & Meloun II & $y_{i}=\beta_{1}-e^{\left(-\beta_{2}-\beta_{3} x_{i}\right)}+e_{1}$ \\
\hline
\end{tabular}

Table 2.

Results of the Quality-of-fit Criteria for the Awassi Sheeps

\begin{tabular}{|c|c|c|c|c|c|}
\hline Model & $\mathbf{R}_{\text {aj }}^{2}$ & AlC & $\mathrm{BIC}$ & MEP & $\mathbf{R}_{\mathrm{P}}^{2}$ \\
\hline Schnute & 0,9554 & 48,1214 & 50,1464 & 3,9641 & 0,9914 \\
\hline Mitscherlich & 0,9905 & 29,2778 & 31,3878 & 0,5675 & 0,9954 \\
\hline Gompertz & 0,9966 & 28,3553 & 30,5427 & 0,4884 & 0,9996 \\
\hline Logistic & 0,9888 & 30,0104 & 32,3261 & 0,6128 & 0,9924 \\
\hline Von Bertalanffy & 0,9961 & 30,1226 & 32,3915 & 0,4036 & 0,9991 \\
\hline Michaelis-Menten & 0,9899 & 29,3664 & 31,8548 & 0,6009 & 0,9934 \\
\hline Meloun II & 0,9905 & 29,2778 & 31,8256 & 0,5678 & 0,9954 \\
\hline Mean & 0,9891 & 31,0493 & 33,3224 & 0,8745 & 0,9961 \\
\hline
\end{tabular}

Table 3.

Results of the Isotonic Regression with Four Models

\begin{tabular}{|c|c|c|c|c|}
\hline Models & Methodology & $\% \mathrm{C}$ & MSE & $\mathbf{R}^{2}$ \\
\hline \multirow[t]{2}{*}{ Richards } & Original (y) & 100 & 16,5114 & 0,9874 \\
\hline & Simple isotonic regression $\left(y^{*}\right)$ & 100 & 15,7802 & 0,9872 \\
\hline \multirow[t]{2}{*}{ Gompertz } & Original (y) & 100 & 19,3656 & 0,9778 \\
\hline & Simple isotonic regression ( $\left.\mathrm{y}^{*}\right)$ & 100 & 19,8824 & 0,9705 \\
\hline \multirow{2}{*}{ Brody } & Simple isotonic regression $\left(\mathrm{y}^{*}\right)$ & 86 & 17,0837 & 0,9815 \\
\hline & Weighted isotonic regression $\left(\mathrm{y}^{* *}\right)$ & 88 & 13,8619 & 0,9916 \\
\hline \multirow[t]{2}{*}{ Von Bertalanffy } & Original (y) & 88 & 12,1208 & 0,9918 \\
\hline & Simple isotonic regression $\left(\mathrm{y}^{*}\right)$ & 90 & 13,4178 & 0,9908 \\
\hline
\end{tabular}


sheep. Therefore, based on the MSE and $\mathrm{R}^{2}$ value, it is possible to conclude that the Von Bertalanffy model best predicts the weight of Awassi sheep in the conditions of this study, through isotonization of the data with different weights. Topal and Macit (2004) were reported that in their study on 66 Morkaraman sheep, as a result of multiple regression analysis, the $\mathrm{R}^{2}$ value of body length affecting body weight was 0.282 and MSE value was 31.702 . In addition, the fact that it provides $92 \%$ convergence shows that this model has benefits in terms of ease of convergence as well as the quality of fit.

\section{Conclusion}

As a result of different non-linear models that were used to predict the growth curves of Awassi sheep and the isotonic regression analysis applied to these models, the Von Bertalanffy model was found to be the most appropriate model when MSE and $\mathrm{R}^{2}$ were taken into account. As a result, it was revealed that the percentage of predictability and goodness of fit of the models increased significantly with isotonic regression analysis and could be made more consistent estimations for adult weight.

Etik Komite Onayı: N/A.

Hakem Değerlendirmesi: Dış Bağımsız.

Çıkar Çatışması: Yazarlar çıkar çatışması bildirmemişlerdir.

Finansal Destek: Yazarlar bu çalışma icin finansal destek almadıklarını beyan etmişlerdir.

Ethics Committee Approval: N/A.

Peer-review: Externally peer reviewed.

Conflict of Interest: The author declared that no conflict of interest on this article submission.

Financial Disclosure: The authors declared that this study has received no financial support.

\section{References}

Akbaş, Y., Taskin, T., \& Demiroren, E. (1999). Comparison of several models to fit the growth curves of Kivircik and Daglic male lambs. Turkish Journal of Veterinary and Animal Science, 23, 537-544.

Aytekin, I., Karabacak, A., Zülkadir, U., Keskin, I., \& Boztepe, S. (2009). Usage of some models for describing the growth curves of Akkaraman and Anatolia Merino lambs raised in open and closed sheepfolds at the fattening period. Selçuk Journal of Agriculture and Food Sciences, 23(49), 30-35.

Aytekin, I., Zulkadir, U., Keskin, I., \& Boztepe, S. (2010). Fitting of different mathematic models to the growth curves of femaleMalya lambs weaned at two different live weights. Trends Anim. Veterinary Sciences, 1, 19-23.

Barlow, R. E. (1972). Statistical inference under order restrictions: The theory and application of isotonic regression. London: J. Wiley.

Bilgin, O. C., Esenbuga, N., Macit, M., \& Karaoglu, M. (2004). Growth curve characteristics in Awassi and Morkaraman sheep, Part I: comparison of nonlinear functions. Wool Technology and Sheep Breeding, 52, 1-7.

Carneiro, P. L. S., Malhado, C. H. M., Souza Júnior, A. A. Od, Silva, A. G. Sd, Santos, F. Nd, Santos, P. F., \& Paiva, S. R. (2007). Desenvolvimento ponderal e diversidade fenotípica entre cruza-mentos de ovinos Dorper com raças locais. Pesquisa Agropecuária Brasileira, 42(7), 991-998. [CrossRef]

Ghafouri-Kesbi, F. G., \& Notter, D. R. (2016). Sex influence on genetic expressions of early growth in Afshari lambs. Archives Animal Breeding, 59(1), 9-17. [CrossRef]

Gunn, L. H., \& Dunson, D. B. (2005). A transformation approach for incorporating monotone or unimodal constraints. Biostatistics, 6(3), 434-449. [CrossRef]

Hussian, M., Grimval, A., Burdakov, O., \& Sysoev, O. (2004). Monotonic regression for assessment of trends in environmental quality data. Eccomas Jyvaskyl, 1, 24-28.

Lewis, R. M., Emmans, G. C., Dingwall, W. S., \& Simm, G. (2002). A description of the growth of sheep and its genetic analysis. Animal Science, 74(1), 51-62. [CrossRef]

Malhado, C. H. M., Carneiro, P. L. S., \& Mello, P. R. A. M. (2009). Growth curves in Dorper sheep crossed with the local Brazilian breeds. Morada Nova. Rabo Largo. and Santa Inês. Small Ruminant Research, 84, 16-21.

Mendes, P. N., Muniz, J. A., Silva, F. F., Mazzini, A. R. A., \& Silva, N. A. M. (2009). Análise da curva de crescimento difásica de fêmeas Hereford por meio da função não-linear de Gompertz. Ciência Animal Brasileira, 10(2), 454-461.

R Core Team. (2014). R: A language and environment for statistical computing. Vienna: R Foundation for Statistical Computing. Retrieved from http://www.R-project.org

Ramsay, J. O. (1998). Estimating smooth monotone functions. Royal Statistical Society, 60(2), 365-375. [CrossRef]

Silveira, F. Gd, Silva, F. Fe, Carneiro, P. L. S., Malhado, C. H. M., \& Muniz, J. A. (2011). Análise de agrupamento na seleção de modelos de regressão não-lineares para curvas de crescimento de ovinos cruzados. Ciência Rural, 41(4), 692-698. [CrossRef]

Topai, M., \& Macit, M. (2004). Prediction of body weight from body measurements in Morkaraman sheep. Journal of Applied Animal Research, 25(2), 97-100. [CrossRef] 